\title{
FISCAL DISTRESS OF LOCAL GOVERNMENT STUDY ON REGENCIES/CITIES IN THE PROVINCES OF EAST NUSA TENGGARA, MALUKU, AND NORTH MALUKU
}

\author{
Abdul Halim ${ }^{\star}$ \\ Maria Odriana Veronica Moi \\ Revrisond Baswir \\ Universitas Gadjah Mada
}

\begin{abstract}
This study aims to examine the factors that influence the occurrence of fiscal distress in local government. The degree of decentralization, local financial dependency ratio and local financial independence ratio were used to predict fiscal distress. The method used in this study is a quantitative research and used the regencies/cities in the province of East Nusa Tenggara, Maluku and North Maluku were taken as samples. The results showed different result with previous studies, that the degree of decentralization, local financial dependency ratio and local financial independence ratio do not affect the fiscal distress.
\end{abstract}

Keywords: Fiscal Distress; Decentralization; Financial Dependency; Financial Independence

\section{INTRODUCTION}

The purpose of this study was to examine empirically the factors that may influence the occurrence of fiscal distress in local government. This study was motivated by the condition of the government as an entity that provides services to the public, with limited resources. Limitations that obstruct the achievement of all the needs led the government from the financial side, failed in performing their ministerial duties. This failure is known as fiscal distress. Knowledge of fiscal distress itself becomes an important thing, hence the financial condition that is healthy or not will affect the performance of the government as a provider of services to the community in various fields, such as transportation, health and education.

Financial capability or failure that is experienced by the government, it will affect the service to the community. In order to the government can provide optimum service, the government needs to pay attention to their own financial health (Trussel \& Patrick, 2009). Jones \& Walker (2007) define fiscal distress as the incapability of the government to provide public services in accordance with service quality standards have been set. Honadle, Costa \& Cigler (2004) in Trussel \& Patrick (2009) argue that when the government is able to overcome the condition of fiscal distress, then directly the government has maintained their capability in providing services to the public. Fiscal distress is one of the issues that affect economic, social and political condition and can give a significant influence on the economic development in the next period of local government (Carmeli, 2007 in Carmeli, 2008). Atmaja (2012) mentions fiscal distress as an initial condition / indication of deterioration of local government. 
Fiscal Distress of Local Government Study on Regencies/Cities in the Provinces of East Nusa Tenggara, Maluku, and North Maluku

Abdul Halim, Maria Odriana Veronica Moi, Revrisond Baswir

Failure or fiscal distress that occurs is caused by various factors. In developed countries, Carmichael \& Midwinter (1999) suggest that factor affecting the condition of fiscal distress in Glosgow, cities in the UK, Netherlands and Germany in the 1990s is lack of revenue to finance expenditure devoted to the provision of public services. Fiscal distress also caused by budget deficits in European countries (Carmichael \& Midwinter, 1999). Expenditure devoted to public services is expenditure in the provision of facilities and infrastructure for the community. Capital expenditure is an item that contains the development plans and the provision of such facilities. Jones \& Walker (2007) measure fiscal distress by looking at the government's capability to maintain the infrastructure that is in the Australian government. Wicaksono (2015) suggests that the allocation of capital expenditure will affect public services through the development and improvement of infrastructure. This will prevent the occurrence of fiscal distress. Bahl (1984) suggests that research related to fiscal distress has not produced a consensus (final conclusions). Therefore, research on the influencing factors still need to be done to provide additional empirical evidence, particularly the sample in the study that may be different.

This study is a modification of the research of Trussel \& Patrick (2009) and some previous studies, namely Brown (1993) and Carmichael \& Midwinter (1999), by using indicators that are adjusted to the condition of financial data from the sample studied. Researchers chose districts / cities in the province of East Nusa Tenggara, Maluku and North Maluku. Selection of these samples considering the condition of the local government and development going on in the provinces, which is likely to affect the level of needs fulfilment of public services, as well as the revenue received, which affect the amount of additional funds allocation from the central government. The reason is the same as proposed by (Stevens \& LaPlante, 1987), choosing more specific areas and limited to homogeneous areas of specific aspects.

Data collected from 2010-2012. Factors that influence the occurrence of fiscal distress are the degree of decentralization, local financial dependency ratio, and local financial independence ratio. Classification of areas into fiscal distress status and non fiscal distress will follow the research of Wicaksono (2015) which uses the ratio of capital expenditure to total expenditure. Service task that is carried to the government demanding the government to work as a service provider central that is to provide resources, use it to bring results in the form of changes in quality of life or society welfare. Government's failure in carrying out this task will affect how much the changes that will occur in the society. Fiscal distress as an indicator of financial failure that is experienced by government will disrupt the process of services to the public. Beginning with the role of government as an agent that is described in agency theory (Jensen \& Meckling, 1976), the government plays an important role in meeting the needs of principal or society. The government is expected to be able to fulfil the needs by managing existing resources, holding responsible it to the public through the provision of facilities, public service facilities. It is intended to maintain public trust as principal, as have selected an agent.

Later, the government is given a wider opportunity with the existence of regional autonomy. In relation to regional autonomy, as mandated by the 1945 Constitution of the Republic of Indonesia, local government is declared having the power to regulate and manage their own affairs in accordance with the principle of autonomy and duty of assistance. Since the enactment of Law No. 22 of 1999, the government 
implemented regional autonomy in order to the implementation of government affairs that is more efficient, effective and responsible (Nordiawan and Hertianti, 2016).

The implementation of regional autonomy can influence people's lives in various fields. In the concept of regional autonomy, government and society in a region have an important role in improving development quality in their respective areas (Syurmitha, 2014 in Sartika, 2016). Development quality is supported by budget allocation for the provision of facilities and infrastructure in the region. The provision of facilities and infrastructure will support the services given to the public. Provision of facilities allocated in the capital expenditure budget is expected to have a greater proportion from other expenditures (personnel expenditures). In a document issued by the government which is passed by presidential decree or local regulation, set limits that must be fulfilled by local government related to capital for the provision of public services facilities. When governments are unable to provide public services because of uncontrolled spending on routine expenditure, then it is possible that the government will run into fiscal distress.

Another thing that is also related to fiscal distress is regional imbalances that occur between developed region and developing region. Wicaksono (2015) uses the theory of regional imbalances to explain the possibility of fiscal distress in Indonesia. Yuana (2014) in Wicaksono (2015) argues that regional imbalances in Indonesia occurred since fiscal decentralization. Regions that are able to produce high local revenues will be more advanced, while areas that cannot produce high local revenues will be increasingly left behind in terms of economy and development. Here, fiscal distress will be more likely to occur in regions with low local revenues, hence the number of revenues that is obtained also contributes to the possibility of budget allocation for infrastructure development.

Fiscal distress is defined in various ways both in the sector of profit, non-profit and government. Most definitions explain fiscal distress as arising thing caused by financial problems (Trussel \& Patrick, 2009). Trussel (2002), Trussel \& Greenelee (2004) defines fiscal distress for non-profit organizations, that is a significant decrease of resources in the form of revenue or net assets, or expenses for programs carried out continuously. DeSanto et al. (1991) in Trussel \& Patrick (2009) defines fiscal distress as a deficiency that occurs continuously from cash flow, resulting from an imbalance between revenue and expenditure for each level of services provided. Fiscal distress also be regarded as a failure to meet the standards in the field of debt operasil and community needs in a row (Kloha, Weissert, \& Kleine, 2005). Trussel \& Patrick (2009) define fiscal distress as a significant and continuously imbalance between revenue and expenditure.

Fiscal distress according to Jones \& Walker (2007) is the incapability of the government to provide services to the public in accordance with service quality standards have been set. It is due to the government does not have the availability of funds to be invested in infrastructure that is used in the provision of service to the public (Atmaja, 2012). This lack or unavailability condition of funds indicates that the government is experiencing financial difficulties (Sutaryo et al, 2012). Clark (1977) discusses four indicators of financial limitation or fiscal of the government is: Probability of default, which is defined as the inability of local governments to pay bond; Ratio indicators, such as gross debt divided by taxes based on short-term debt; 
Fiscal Distress of Local Government Study on Regencies/Cities in the Provinces of East Nusa Tenggara, Maluku, and North Maluku

Abdul Halim, Maria Odriana Veronica Moi, Revrisond Baswir

Social and economic based indicators, such as population size and average revenue per capita; Indicator of cash flow.

Research from Trussel \& Patrick (2013) describes revenue concentration as one symptoms of fiscal distress. Revenues that earned in the district and the city comes from a variety of sources including taxes and other government. The more the government's access to funding sources, the more efficient the government in raising capital, and less likely to run into fiscal distress (Trussel \& Patrick, 2009). The degree of decentralization reflects the degree of Own Source Revenue (PAD) contribution to total local revenues. In this case, the revenue that earned is derived from sources within the region itself, in the form of local taxes, retribution and other legitimate local revenues. The higher PAD contribution to total revenue earned, the higher government's capability organizes decentralization (Mahmudi, 2016). When the government is able to organize decentralisation well, then the services provided and the possibility of increasing the allocation for capital expenditure will also increase. The increase in capital expenditures derived from local revenues, which is used to increase service capacity, will further minimize the possibility of fiscal distress. Research of Trussel \& Patrick (2009; 2013) shows that revenue concentration influences on fiscal distress. This is supported by research from Syurmitha (2014) in Sartika (2016). Based on the explanation then formulated the following hypotheses:

H1: degree of decentralization affects on the occurrence of fiscal distress.

Local financial dependency explains how large a proportion of revenue that is received by local governments from central government. The higher the dependency ratio, the greater the local government dependency level to the central government (Mahmudi, 2016). The funds that are received by local governments from the central government used to fulfil adequacy in funding programs / activities planned in the region. Financing that is more comes from outside the region indicating that fiscal strength in the region is still weak to fulfil all needs. This weakness can cause fiscal distress. Research of Tubels (2015) states showing that the vulnerability of fiscal distress caused by lack of local governments independence. Independence itself can be measured by the decrease in additional funding from outside the local government. Based on this explanation, then formulated the following hypothesis:

H2: Local financial dependency ratio affects on fiscal distress

Local independence demonstrates the ability of regions in digging the potency that is owned by the region into a source of revenue which can finance most of the expenditures budgeted. Local financial independence ratio implies a comparison between the number of Own Source Revenue (PAD) and the amount of transfer revenue from central and local government as well as local loans. The higher this ratio shows the government is increasingly independent in their local financial (Mahmudi, 2016). Higher financial independence will make the government is more able to finance their needs in order to services to the public. This will minimize the possibility of fiscal distress. Syurmitha (2014) in Sartika (2016) showed that financial independence influences on fiscal distress prediction. Research of Sartika (2016) also showed similar results. Therefore, the third hypothesis is formulated as follows:

$\mathrm{H} 3$ : local financial independence influences on the occurrence of fiscal distress 


\section{METHODS}

This study was quantitative descriptive research. The population in this study was the districts and cities in the province of East Nusa Tenggara, Maluku and North Maluku, with financial data from 20112012. Samples were obtained by using purposive sampling technique, which was the area with the availability of complete data. The data used in this research was secondary data, namely the financial statements years 2010-2012 that obtained from the Directorate General of Regional Financial Balance. The data used was the realization of Regional Governemnt Budget of each district and city. Data would be analyzed using logistic regression. This was due to the dependent variable was categorical (distress and nondistress).

Status $=\alpha+\beta_{1}$ DESENTR $+\beta_{2}$ KETERGNT $+\beta_{3}$ KEMANDR $+e$

Explanation:

Status $\quad$ : fiscal distress $(0=$ non distress, $1=$ distress $)$

DESENTR : degree of decentralization

KETERGNT : local financial dependency ratio

KEMANDR : local financial independence ratio

a : constants

$\beta \quad$ : regression coefficient

e : error terms

Dependent variables in this study were the status of fiscal distress and non-distress. Determination of the status is based on the proportion of capital expenditure to total expenditure. The provision of expenditure proportion adapted to the provision of Presidential Decree No.5 of 2010 on the National Medium Term Development Plan for Years 2010-2012, which also contained a percentage of average capital expenditure to total local expenditure. The percentage in 2010 is set at $26 \%$, year 2011 is set at $27 \%$ and in 2012 is set at $28 \%$. Degree of decentralization is the ratio between the amount of own source revenue (PAD) to local revenue. The ratio of local dependency is the ratio of transfer revenue number that is received by local acceptance with total local revenues. Local financial independence ratio is the ratio of the number of Own Source Revenue acceptance divided by the number of transfers revenue from central government and the provinces with regional loan (Mahmudi, 2016).

\section{RESULTS AND DISCUSSIONS}

Sample regional status determination including distress or non-distress category based on the ratio of capital expenditure to total regional expenditure. Region classified as fiscal distress was numbered 1, while region that classified as non-distress was given number 0 . Based on the sample selection with purposive sampling method, samples obtained were as many as 81 samples (samples with complete data multiplied by years of data used) ie $27 \times 3$ years. Hypothesis testing results showed that the variables of degree of decentralization (DESENTR), local financial dependency ratio (KETERGNT) and local financial 
Fiscal Distress of Local Government Study on Regencies/Cities in the Provinces of East Nusa Tenggara, Maluku, and North Maluku

Abdul Halim, Maria Odriana Veronica Moi, Revrisond Baswir

independence ratio (KEMANDR) did not influence on fiscal distress / non fiscal distress condition. Goodness of fit of the model was not able to predict observation values or did not match the data used in the study. It could be seen from the value of Hosmer and Lemeshow Test was equal to 0,020, or less than 0.05 . The test results of determination coefficient showed that variability of dependent variables that could be explained by independent variability was 3.5\% based on the value of Nargelkerke R Square. The value of model forecast accuracy was $65.4 \%$.

Table 1. The Results of Hypothesis Testing

\begin{tabular}{llll}
\hline Variable & $\begin{array}{l}\text { Regression } \\
\text { Coefficient }\end{array}$ & Sig & Conclusion \\
\hline DESENTR & $-0,133$ & 0,262 & Not significant \\
KETERGNT & $-0,129$ & 0,269 & Not significant \\
KEMANDR & $-0,717$ & 0,647 & Not significant \\
\hline
\end{tabular}

Source: data processed, 2016

The first hypothesis testing showed that the degree of decentralization did not affect to the fiscal distress of local government. The first hypothesis was rejected. It could be seen from significance value as big as 0.262 was greater than 0.05 . The results of this study supported previous study results of Sartika (2016) which showed that decentralization did not affect to the fiscal distress experienced by local governments. Negative coefficient showed that the higher the degree of decentralization of local government, the less likely fiscal distress occurred. The degree of decentralization is PAD comparison with the total revenue of the region. The second hypothesis testing showed that local financial dependency ratio did not affect to the fiscal distress. Significance value of this variable on the condition of fiscal distress amounted to 0.269 greater than 0.05 . The second hypothesis was rejected. Coefficient value of the variable amounted to -0.129 which was negative showed that there was a negative relationship between the local financial dependency ratio and fiscal distress. When the government experienced a high dependency on transfer revenue, the smaller the government's tendency to experience fiscal distress. The third hypothesis testing was the effect of local financial independence ratio to the fiscal distress was not supported. A significance value of 0.647 was greater than 0.05 . The coefficient value of -0.717 indicated that the higher the financial independence, the less likely the occurrance of fiscal distress and vice versa. The results showed that these three variables did not give effect to the fiscal distress in local government. These results are in contrast to previous studies conducted (Syurmitha, 2014 in Sartika, 2016); Wicaksono, 2015; Trussel \& Patrick, 2009). These results indicated that although the government was trying to increase capacities and capabilities in financing the needs, fiscal distress could occur when needs met was administrative and not to the provision of facilities or capital expenditures. As from the data obtained, average capital expenditure allocated was lower than the target set by the government. Local revenue with large numbers did not guarantee allocation of capital expenditure would also increase, if the government did not suppress administrative expenses such as personnel expenses. 


\section{CONCLUSION}

This study aims to determine fiscal distress that occurred in the districts and cities in the province of East Nusa Tenggara, Maluku and North Maluku and examine the effect of the degree of decentralization, local financial dependency ratio and local financial independence ratio to the fiscal distress that occurs. The results showed that fiscal distress is experienced by the city and district government that used as samples in the study. Hypothesis testing results showed that the degree of decentralization, local financial dependency ratio and local financial independence ratio did not influence to fiscal distress that occurred in the district and the city government of East Nusa Tenggara, Maluku and North Maluku. The results showed a negative relationship between these three variables with the conditions of fiscal distress in the region.

Limitation of this study is the number of samples in the amount of 81. Long (1997) in Gudono (2015) suggested that the minimum sample amounted to 100. In addition, data condition that will be observed will affect the results. In this study, range of data observed affected the results of hypothesis testing. When range of data tended not to be same or vastly different range, it will affect the results obtained. Hence, it is expected for further research is able to consider the number of samples and data to be used in the analysis. Further research can use another proxy in determining the status of fiscal distress in local government and add other variables to create better predictive models. This study is expected to be able to add references for further research and being a source of study for local government in maintaining their financial health through policies established in order that the process of service to the public can be maintained from both quality and quantity aspects.

\section{REFERENCES}

Atmaja, K. F. (2012). Analisis Rasio Keuangan Untuk Memprediksi Kemungkinan Financial Distress. Accounting Analysis Journal, 1(2).

Brown, K. W. (1993). The 10-point test of financial condition: Toward an easy-to-use assessment tool for smaller cities. Government Finance Review, 9, 21.

Carmeli, A. (2008). The fiscal distress of local governments in Israel: Sources and coping strategies. Administration \& Society, 39(8), 984-1007.

Carmichael, P., \& Midwinter, A. (1999). Glasgow: Anatomy of a fiscal crisis. Local Government Studies, 25(1), 84-98.

Clark, T. N. (1977). Fiscal management of American cities: Funds flow indicators. Journal of Accounting Research, 5494.

Elde, S. D. 2013. Defeating Fiscal Distress: A State Responsibility. CIVIC REPORT No. 78 July.

Gregory, W. D., Luigi M. (2015). Determinants of Fiscal Distress in Italian Municipalities. Quardeni - Working Paper DES N 1024.

Gudono. (2015). Analisis Data Multivariat Edisi Keempat. Yogyakarta: BPFE

Inmam, R. P. (1995). How to Have a Fiscal Crisis: Lessons from Philadelphia. The American Economic Review, 85 (2), 378-383

Jones, S., \& Walker, R. G. (2007). Explanators of local government distress. Abacus, 43(3), 396-418. 
Fiscal Distress of Local Government Study on Regencies/Cities in the Provinces of East Nusa Tenggara, Maluku, and North Maluku

Abdul Halim, Maria Odriana Veronica Moi, Revrisond Baswir

Kloha, P., Weissert, C. S., \& Kleine, R. (2005). Developing and testing a composite model to predict local fiscal distress. Public Administration Review, 65(3).

Mahmudi. (2016). Analisis Laporan Keuangan Pemerintah Daerah. Yogyakarta: UPP STIM YKPN

Nordiawan D., Ayuningtias H. (2016) Akuntansi Sektor Publik. Jakarta: Salemba Empat

Peraturan Presiden No.5 Tahun 2010 tentang Rencana Pembangunan Jangka Menengah Nasional Tahun 2010-2012

Perlman, B. J. (2009). Fiscal Distress and Governance Challenges: The Perfect Storm of the Fiscal Crisis. State \& Local Government Review, 41 (3), 201-207

Peraturan Presiden No.5 Tahun 2010 tentang Rencana Pembangunan Jangka Menengah Nasional Tahun 2010-2012

Perlman, B. J. (2009). Fiscal Distress and Governance Challenges: The Perfect Storm of the Fiscal Crisis. State \& Local Government Review, 41 (3), 201-207

Ryan, C., Robinson, Marc, Grigg, T. (2000). Financial Performance Indicators for Australian Local Government. Accounting, Accountability and Performance pp 89-106

Sartika, D. (2016). Analisis Prediksi Finansial Distress Pemerintah Daerah Kabupaten/Kota di Indonesia Periode 2011-2013. Naskah Publikasi Jurnal Ilmiah UMS.

Stevens, J. M., \& LaPlante, J. M. (1987). Shaping State-Based Financial Policy In An Era Of Chance: A Policy And Research Perspective On City Size. Review of Policy Research, 7(1), 61-76.

Sukirno. (2014). Kegunaan Laporan Keuangan untuk Memprediksi Financial Distress pada Koperasi di Kabupaten Pemalang. Jurnal Akuntansi dan Keuangan (JAKA) Vol.1 No.1 September pp 10-25

Sutaryo, Sutopo, Rahmawati. (2012). Nilai Relevan Informasi Laporan Keuangan Cash Modified Basic: Kemampuan Rasio Keuangan dalam Memprediksi Status Financial Distress Pemerintah Daerah di Indonesia. File diunduh dari www.multiparadigma.lecture.ub.ac.id

Sutaryo. (2010). Nilai Relevan Informasi Laporan Keuangan Terkait Financial Distress Pemerintah Daerah. Simposium Nasional Akuntansi XIII Purwokerto. File diunduh dari www.multiparadigma.lecture.ub.ac.id

Trussel, J. M., \& Patrick, P. A. (2009). A predictive model of fiscal distress in local governments. Journal of Public Budgeting, Accounting \& Financial Management, 21(4), 578.

Trussel, J. M., \& Patrick, P. A. (2013). Predicting fiscal distress in special district governments. Journal of Public Budgeting, Accounting \& Financial Management, 25(4), 589.

Tubels, A. 2015. Evaluasi Financial Distress pada Pemerintah Kota Bandar Lampung. Jurnal Akuntansi.

Wicaksono, A. (2015). Finansial Distress pada Pemerintah Daerah Kabupaten dan Kota di Indonesia. Tesis. Diunduh dari digilib.uns.ac.id

www.djpk.depkeu.go.id 